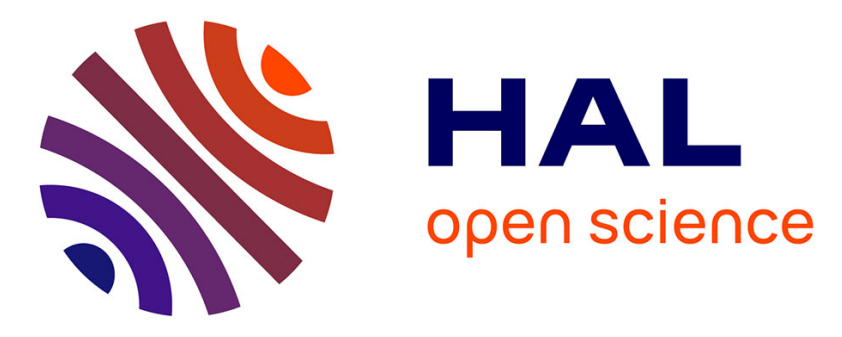

\title{
Does Kamchatka belong to North America? An extruding Okhotsk block suggested by coastal neotectonics of the Ozernoi Peninsula, Kamchatka, Russia
}

Kevin Pedoja, Joanne Bourgeois, Tatiana Pinegina, Bretwood Higman

\section{To cite this version:}

Kevin Pedoja, Joanne Bourgeois, Tatiana Pinegina, Bretwood Higman. Does Kamchatka belong to North America? An extruding Okhotsk block suggested by coastal neotectonics of the Ozernoi Peninsula, Kamchatka, Russia. geological society of america, 2006, 34 (5), pp.353-356. 10.1130/G22062.1. hal-00992588

\section{HAL Id: hal-00992588 \\ https://hal.science/hal-00992588}

Submitted on 27 Aug 2019

HAL is a multi-disciplinary open access archive for the deposit and dissemination of scientific research documents, whether they are published or not. The documents may come from teaching and research institutions in France or abroad, or from public or private research centers.
L'archive ouverte pluridisciplinaire HAL, est destinée au dépôt et à la diffusion de documents scientifiques de niveau recherche, publiés ou non, émanant des établissements d'enseignement et de recherche français ou étrangers, des laboratoires publics ou privés. 


\title{
Does Kamchatka belong to North America? An extruding Okhotsk block suggested by coastal neotectonics of the Ozernoi Peninsula, Kamchatka, Russia
}

\author{
Kevin Pedoja Key Laboratory of Marginal Sea Geology, South China Sea Institute of Oceanology, and Guangzhou Institute of \\ Geochemistry, China Academy of Sciences, Guangzhou, PR China \\ Joanne Bourgeois Department of Earth and Space Sciences, University of Washington, Seattle, WA 98195, USA \\ Tatiana Pinegina Institute of Volcanology and Seismology, FED, Petropavlovsk-Kamchatskiy, 683006, Russia \\ Bretwood Higman Department of Earth and Space Sciences, University of Washington, Seattle, WA 98195, USA
}

\begin{abstract}
This paper addresses one part of an outstanding tectonic problem regarding the nature of the plate boundary between Eurasia and North America in northeastern Russia. In this region, the northwestern corner of the Pacific plate interacts either simply with the North American plate, or more complexly with one or more blocks independent of North America. North of this corner, evidence of uplift, tilting, and convergence contradicts the prevailing, simpler model. On the Ozernoi Peninsula, $\sim 150 \mathrm{~km}$ north of the subducting Pacific plate, marine terraces indicate uplift rates of 0.1 to $0.3 \mathrm{~mm} / \mathrm{yr}$, with faster rates to the east. Historic and paleoseismic records provide evidence for recurring tsunamigenic, thrust earthquakes offshore of the Ozernoi Peninsula, the most recent a Mw 7.7 earthquake in 1969. A multiplate model where an eastward-moving Okhotsk block, including most of Kamchatka, is converging with a clockwise-rotating Bering block better explains these observations than does the unbroken North American plate model.
\end{abstract}

Keywords: Kamchatka, Quaternary marine terraces, neotectonics, plate tectonics, Okhotsk, Bering Sea.

\section{INTRODUCTION AND SETTING}

Does Kamchatka belong to North America or not? Where and how does the North American plate terminate after the Atlantic-Arctic spreading ridge passes through its Euler pole in northeastern Russia (Fig. 1)? This region remains "the last frontier of plate tectonics" (Cook et al., 1986). On the Pacific plate side, the northwestern corner of the Pacific plate is well defined by subduction along the KurilKamchatka trench and transcurrent motion along the Komandorskii ${ }^{1}$-Aleutian trench (Fig. 1). Just north of the KomandorskiiAleutian trench, the Komandorskii Island block (McElfresh et al., 2002) has been established by global positioning system (GPS) measurements (Gordeev et al., 2001) to be moving toward Kamchatka, as predicted by geologic evidence of accretion on the Kamchatskii Peninsula (Geist and Scholl, 1994) (Fig. 1). North of the Komandorskii Island block, recent geophysical models and petrologic evidence favor a "torn-slab" scenario, where the Pacific plate has broken off and fallen away (Park et al., 2002; Portnyagin et al., 2005).

Beyond the trenches and the Komandorskii Island block, major puzzles remain. There are

\footnotetext{
${ }^{1}$ Russian place names are transliterated to English using Library of Congress standards; the ending "ii" is commonly spelled "iy" or simply " $\mathrm{i}$ " in other publications.
}

many models and scant data to constrain questions such as, does the North American plate (1) encompass the entire region (the prevailing or conservative view), or (2) is it broken locally into smaller blocks (in addition to the Komandorskii Island block) such as the Bering and Okhotsk blocks (Fig. 1A)? If the latter, where are the boundaries of these blocks in this region, and how are the blocks moving? In a single North American plate model, the Pacific plate converges with southern Kamchatka (North American plate) at a rate of about $8 \mathrm{~cm} / \mathrm{yr}$ (DeMets et al., 1994), but no tectonic activity is predicted north of the Kamchatskii Peninsula. However, convergence in this northern region could be explained if an Okhotsk block (or plate) is moving eastward, extruded by the convergent rotation of the Eurasian plate and the North American plate south of the Euler pole (Cook et al., 1986) (Fig. 1A). Convergence would be enhanced if the Bering block is rotating clockwise (Mackey et al., 1997).

Several approaches can help address such plate-boundary and plate-motion questions, including seismicity patterns (Mackey et al., 2004) and GPS measurements (Takahashi et al., 1999; Steblov et al., 2003). However, the region is only sparsely instrumented, and instrumental and historic records may be too short to resolve long-term trends. In order to garner longer-term histories, our approach to answering these questions is to examine the neotectonics of the Ozernoi Peninsula, and for comparison, the better-understood Kamchatskii Peninsula (sometimes incorrectly called Cape Kamchatka or Kamchatka Mys Peninsula [as in Gaedicke et al., 2000]) just to the south (Fig. 1B). The Kamchatskii and Ozernoi Peninsulas are major promontories in the southwestern Bering Sea (Fig. 1B), underlain by the Komandorskii Basin (Fig. 1B), which is not now seismically active. The western edge of the basin comprises both an extinct subduction zone (Seliverstov, 1998) and the eastern boundary of the Olyutorskii terrane (Garver et al., 2000); this boundary is seismically active (Cook et al., 1986; Mackey et al., 2004).

Both peninsulas exhibit high relief in the east, where marine terraces are prominent (Fig. 2), and lowlands to the west. On the Ozernoi Peninsula, over a proposed OkhotskBering plate boundary (Fig. 1), Holocene and Pleistocene marine terraces exhibit uplift rates comparable to more tectonically active zones on Earth (Lajoie, 1986; Johnson and Libbey, 1997). Moreover, the 1969 Ozernoi Mw 7.7 earthquake and following tsunami are consistent with active convergence. We think that the uplift of both peninsulas is tectonic in origin. Variability in uplift rate is inconsistent with epeirogenic land-level change, and the good fit of data with relatively constant uplift over hundreds of thousands of years is not consistent with glacio-isostatic processes.

\section{METHODS}

We measured the altitude of uplifted late Quaternary marine terraces to calculate uplift rates (as in Lajoie, 1986). The altitude of the shoreline angle, or base of a paleo-sea cliff, is considered most representative of maximum sea level during interglacial times, correlated to odd-numbered marine isotope stage (MIS). Calculation of uplift rates using marine terraces requires correlation of a particular terrace to a particular stage. In our field area, although Pleistocene terraces are clear in the landscape (Fig. 2), they have been affected by fluvial and glacial processes so that marine deposits are either lacking or buried, and direct numerical 

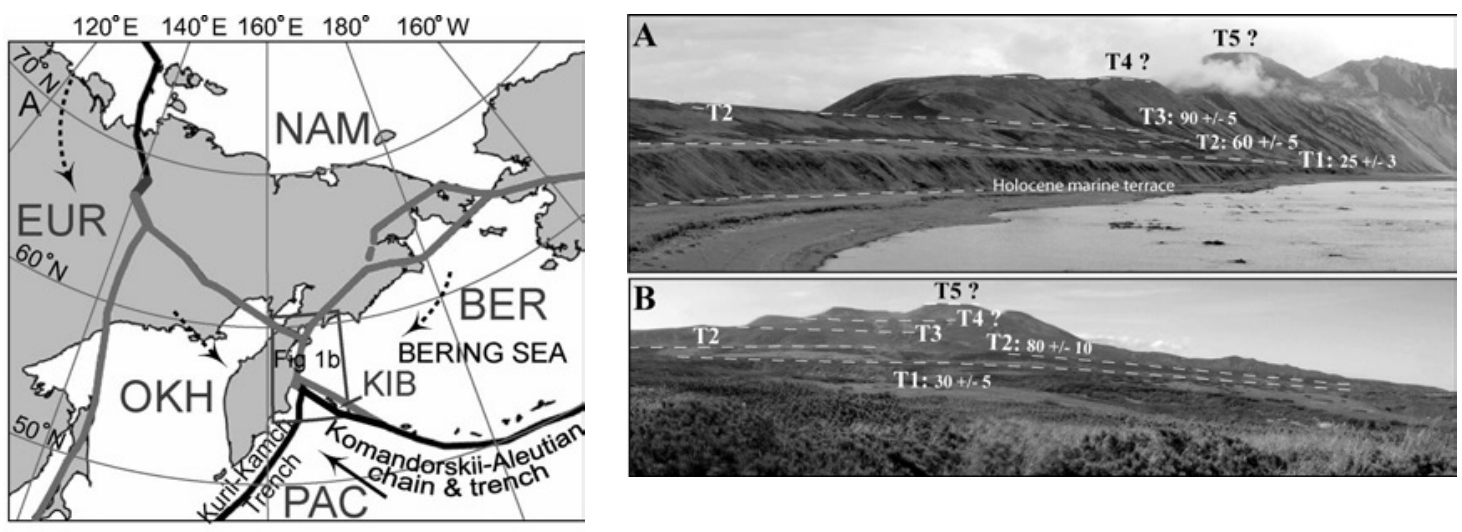

Figure 2. Landscapes showing marine terrace sequences. A: Transect $B$, north side of Cape Nose, Kamchatskii Peninsula (see Fig. 3). B: Transect X, Ozernoi Peninsula (see Fig. 3), from front edge of T1 (lowest Pleistocene terrace).

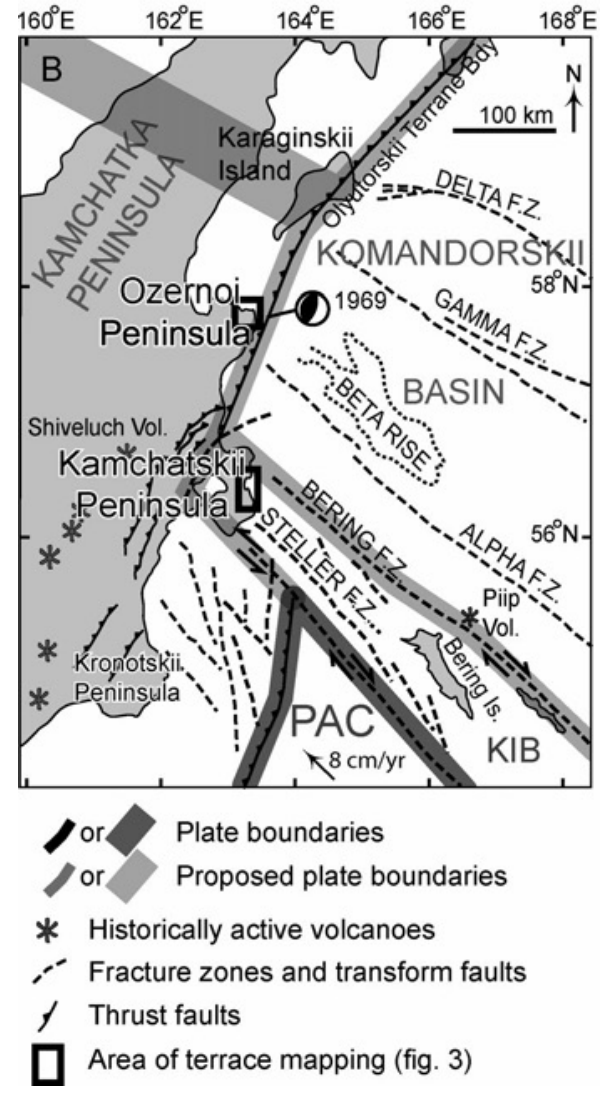

Figure 1. A: Proposed plate and tectonic blocks in northeastern Russia. In the unbroken North American plate model, the Bering and Okhotsk blocks would remain part of the North American plate. NAM-(small) North American plate; EUR-Eurasian plate; PAC-Pacific plate; BER-Bering block (as in Mackey et al., 1997); OKH-Okhotsk block (as in Gordeev et al., 2001); KIBKomandorskii Island block (as in McElfresh et al., 2002). Arrows show suggested motion of plates relative to a fixed (small) NAM. B: Tectonic setting of the northwestern corner of the Pacific plate and western Komandorskii Basin. Compiled and revised from Baranov et al. (1991), Geist and Scholl (1994), Garver et al. (2000), and Gaedicke et al. (2001). The Olyutorskii terrane is also known as the Vetlovka terrane. Also shown: location and fault-plane solution for the 1969 Ozernoi earthquake (Cormier, 1975). The position of the northern boundary of the Okhotsk block is not well defined (shown by broad gray band); some models place it as far south as the Kamchatskii Peninsula. dating of these terraces has not been accomplished. No Pleistocene tephras are well preserved. Thus, we use the standard method of terrace correlation with sea-level highstands (Lajoie, 1986, and many others).

The best-represented terrace worldwide is the one correlated to the Last Interglacial Maximum (MIS 5e) (Hearty and Kindler, 1995; Johnson and Libbey, 1997). The age of MIS 5e is arbitrarily fixed to range from 130 to $116 \mathrm{ka}$ (Kukla et al., 2002) but is demonstrated to range from 134 to $113 \mathrm{ka}$ in Hawaii and Barbados (Muhs et al., 2002) with a peak from 128 to $116 \mathrm{ka}$ on tectonically stable coastlines (Muhs, 2002). Older marine terraces well represented in worldwide sequences are those related to MIS 9 (ca. 303-339 ka) and 11 (ca. 362-423 ka) (Imbrie et al., 1984). Compilations show that sea level was $3 \pm 3$ $\mathrm{m}$ higher than present during MIS 5e, MIS 9, and MIS 11 , and $-1 \pm 1 \mathrm{~m}$ relative to present sea level during MIS 7 (Hearty and Kindler, 1995; Zazo, 1999). Consequently, MIS 7 (ca. 180-240 ka; Imbrie et al., 1984) marine terraces are less pronounced and sometimes absent (Zazo, 1999).

Fieldwork carried out in 2003 included topographic surveys of Holocene beach and terrace profiles and altimeter transects of Pleistocene marine terraces. Along Holocene profiles, we made excavations and used the oldest preserved marker tephra (Braitseva et al., 1997) in soil above marine sand, to establish a minimum terrace age. For Pleistocene marine terraces, we measured altitudes of shoreline angles with digital altimeters calibrated to the most recent high tidemark. Tide tables were used to relate high tide to a mean sea-level datum; all terrace altitudes are given in meters above mean sea level. With the same altimeter, we estimated barometric drift and calibrated on the high tidemark before and after measuring terrace altitudes. As we worked near sea level, the equation relating pressure and altitude does not have to be corrected. The altitude error range in tables and figures comes primarily from a field estimate of paleoshoreline preservation, as barometric drift was relatively small.

\section{DATA AND ANALYSIS}

Holocene Terraces and Sea Level

For a number of sites, we measured the elevation of the back of the Holocene marine terrace and estimated the elevation of the shoreline angle (Table 1) by assuming that mid-Holocene eustatic sea level in the North Pacific was $\sim 2 \mathrm{~m}$ higher than today (Douglas et al., 2001), and that $\sim 5 \mathrm{~m}$ of sediment overlies the wave-cut platform (based on the elevation of modern beach profiles above that platform). At field sites on both peninsulas, the Holocene shoreline began prograding $\sim 5000$ years ago (based on the oldest preserved tephra). There are large uncertainties in the Holocene data, relative to measured elevations, but we consider significant the trend of rising elevation of this shoreline angle toward the outer part of each peninsula, consistent with trends in Pleistocene terrace elevations. Uplift rates for the late Holocene are an order of magnitude faster than Pleistocene rates presented below.

\section{Pleistocene Marine Terraces}

On the outer Kamchatskii Peninsula, we mapped five Late Pleistocene marine terraces along more than $20 \mathrm{~km}$ of rocky coast (Figs. $2 \mathrm{~A}$ and 3). On the northeastern part of the Ozernoi Peninsula, we mapped two marine terraces; in some places, remnants of older terraces were detectable (Figs. 2B and 3), and it was possible to define at least three to five paleoshorelines above the Holocene. Because the elevations of these terraces are an order of magnitude higher than the uncertainties in sediment-cover thickness and paleoeustatic sea level mentioned for the Holocene, these uncertainties have no effect on overall interpretation.

On both peninsulas, following standard practice (Johnson and Libbey, 1997), we correlate the prominent $\mathrm{T} 1$ marine terrace with MIS 5, and in order to get the minimum uplift rate we correlate the shoreline of this terrace with the peak or maximum of this interglacial (MIS 5e) (Fig. 3). This correlation gives longterm uplift rates ranging from $0.10 \pm 0.07$ $\mathrm{mm} / \mathrm{yr}(0.1 \mathrm{~m} / \mathrm{k} . \mathrm{y}$.) to $1.12 \pm 0.20 \mathrm{~mm} / \mathrm{yr}(1$ $\mathrm{m} / \mathrm{k} . \mathrm{y}$.) (Table 1). These rates are comparable 
TABLE 1. TERRACE ELEVATIONS AND CALCULATED UPLIFT RATES

\begin{tabular}{|c|c|c|c|c|c|c|c|c|c|}
\hline \multirow[t]{2}{*}{ Profile } & \multicolumn{4}{|c|}{ Terrace elevation $(\mathrm{m})$} & \multicolumn{5}{|c|}{ Uplift Rate $(\mathrm{mm} / \mathrm{a}$ or $\mathrm{m} / \mathrm{ka})$} \\
\hline & $\mathrm{H}$ & T1 & T2 & T3 & $\mathrm{T} 1=\mathrm{MIS} 5 \mathrm{e}$ & $\mathrm{T} 2=\mathrm{MIS} 7$ & $\mathrm{~T} 2=\mathrm{MIS} 9$ & T3 $=$ MIS 9 & $\mathrm{~T} 3=\mathrm{MIS} 11$ \\
\hline A & n.d. & $22-28$ & $55-65^{\star}$ & $85-95$ & $0.11-0.25$ & $0.22-0.37$ & $0.15-0.23$ & $0.24-0.33$ & $0.19-0.28$ \\
\hline B & 0 & $20-30$ & $55-65^{*}$ & $\sim$ & $0.1-0.27$ & $0.22-0.37$ & $0.15-0.23$ & & \\
\hline $\mathrm{C}$ & $1-2$ & $17-23$ & $47-63^{*}$ & $70-90$ & $0.08-0.21$ & $0.19-0.36$ & $0.12-0.22$ & $0.19-0.31$ & $0.15-0.26$ \\
\hline D & $2-3$ & $42-48$ & $70-80^{\#}$ & $\sim$ & $0.26-0.43$ & $0.28-0.45$ & $0.19-0.28$ & & \\
\hline $\mathrm{E}$ & $>3$ & $63-73$ & $\sim$ & $\sim$ & $0.42-0.65$ & & & & \\
\hline $\mathrm{F}$ & n.d. & $70-80$ & $\sim$ & $\sim$ & $0.47-0.71$ & & & & \\
\hline $\mathrm{G}$ & n.d. & $130-150$ & $\sim$ & $\sim$ & $0.92-1.33$ & & & & \\
\hline Z & 0 & $10-20$ & $32-42$ & $\sim$ & $0.02-0.18$ & $0.12-0.24$ & $0.08-0.15$ & & \\
\hline $\mathrm{Y}$ & $0-1$ & $25-35$ & $\sim$ & $\sim$ & $0.14-0.31$ & & & & \\
\hline$x$ & $1-2$ & $25-35$ & $70-90$ & $\sim$ & $0.14-0.31$ & $0.28-0.51$ & $0.19-0.31$ & & \\
\hline W & 2 & $40-50$ & $\sim$ & $\sim$ & $0.25-0.45$ & & & & \\
\hline \multicolumn{10}{|c|}{$\begin{array}{l}\text { Note: Profile locations and plots of data are shown in Fig. 3; H-Holocene; n.d.-no data near that terrace profile. Error as represented by range of terrace ele vation } \\
\text { is discussed in the text. Age ranges assigned to calculate uplift rates: MIS 5e 113-134 ka (see text); MIS } 7 \text { 180-240 ka; MIS } 9303-339 \text { ka; MIS } 11362-423 \text { ka (Imbrie } \\
\text { et al., 1984). } \\
\text { *Terrace 2a; \#Terrace 2b; not measured with altimeter. }\end{array}$} \\
\hline
\end{tabular}

to uplift rates determined through the same method in other parts of the Pacific rim (Ota and Yamaguchi, 2004).

For carving of the T2 terrace, there are two hypotheses for the MIS responsible (Fig. 3; Table 1). The first hypothesis correlates T2 with MIS 7 (penultimate interglacial, ca. 220 ka, "weaker" than MIS 5e). The second hypothesis correlates T2 with MIS 9 ("strong" interglacial, ca. $330 \mathrm{ka})$. For most transects where $\mathrm{T} 2$ was measured (T2a on $\mathrm{X}, \mathrm{Z}, \mathrm{A}, \mathrm{B}$, $\mathrm{C}$ in Table 1), the latter hypothesis (T2 = MIS 9) produces more uniform uplift rates per transect (Fig. 3). However, for transect D, which has the highest uplift rate for a transect where $\mathrm{T} 2$ was measured, $\mathrm{T} 2 \mathrm{~b}=$ MIS 7 produces the more uniform rate. These results are as expected, because MIS 7 was weaker than MIS

Figure 3. Marine terrace transects on the Kamchatskii and Ozernoi Peninsulas (see Fig. 1B for locations). Plots of displacement of Quaternary shoreline angles against accepted ages of marine terraces corresponding to marine isotope stage (MIS), giving uplift rates (as in Table 1). Width of lines represents estimated error in terrace elevation and MIS age (see Table 1). For all cases, the lowest Quaternary terrace $(\mathrm{T} 1)$ is correlated to MIS 5e. Two alternative interpretations of T2 are presented for each peninsula: T2 $=$ MIS 7, or T2 $=$ MIS 9 (see text and Table 1).

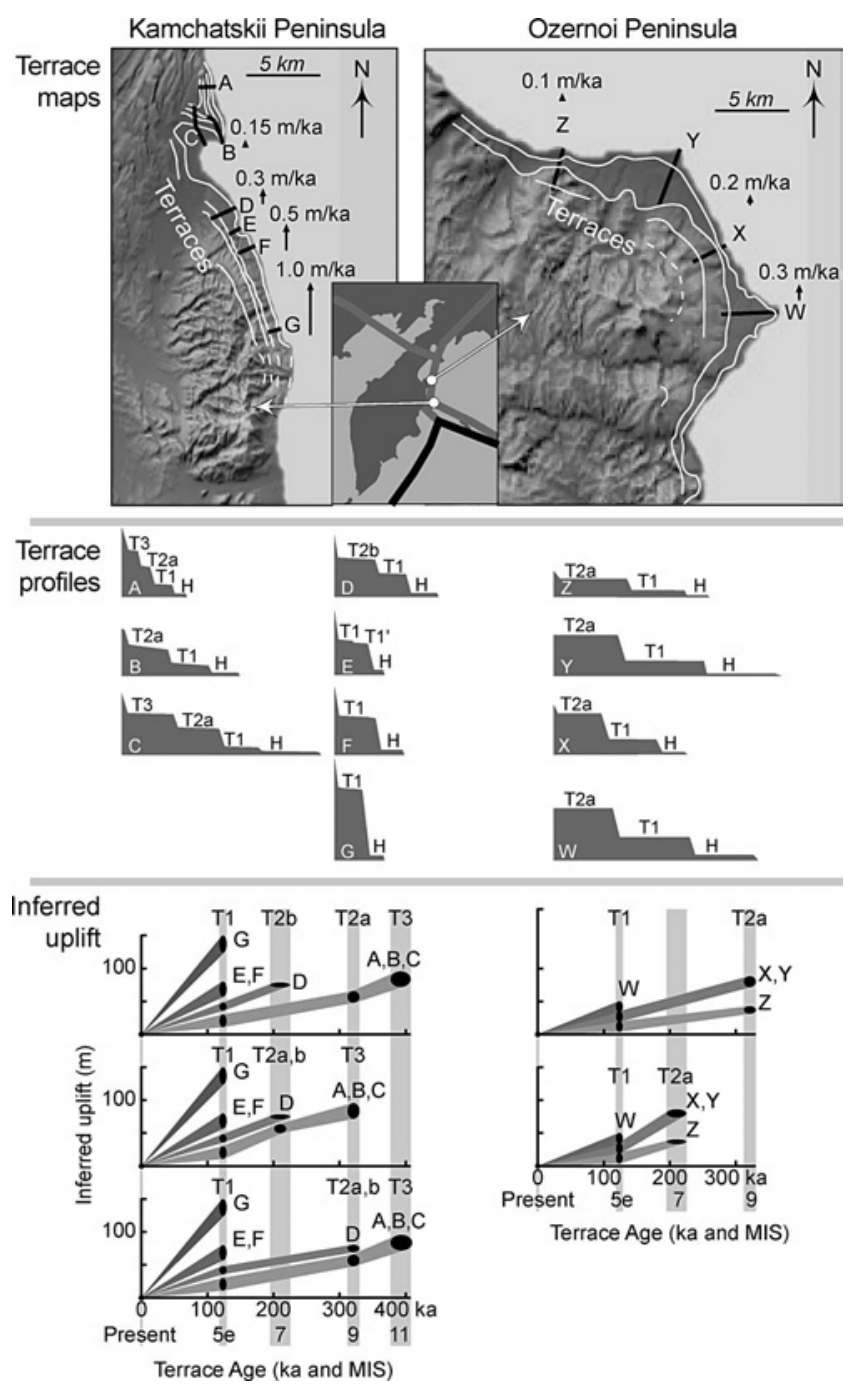

5 or 9 , and its terraces are typically only preserved where uplift rates are more rapid (Zazo, 1999).

On both peninsulas, either hypothesis can fit with the existence and morphology of T3, a wider terrace than $\mathrm{T} 2$; that is, $\mathrm{T} 3$ can be related to MIS 9 or MIS 11. Without direct dating of marine terrace deposits, it is a challenge to address this problem. However, with the exception of transect D and others with faster uplift rates (where T2 and T3 were not measured), we favor the second hypothesis (T2a $=$ MIS 9 and T3 = MIS 11) because it generates nearly constant uplift rates at each profile.

\section{Ozernoi Earthquake and Tsunami}

On 22 November 1969, 23:09:35 GMT (locally midday, 23 November), an earthquake jolted the Ozernoi region. Many different magnitudes for this earthquake have been published; it is currently catalogued with a 7.7 moment magnitude. The epicenter was located at $57.8^{\circ} \mathrm{N}, 163.6^{\circ} \mathrm{E}$, just off the Ozernoi Peninsula (Fig. 1B). Cormier (1975) interpreted this event as a thrust, and using body waveform analysis, Daughton (1990) found a thrust fault-plane solution, striking $\mathrm{N} 50^{\circ}-80^{\circ} \mathrm{E}$ and dipping $5^{\circ}-10^{\circ} \mathrm{NW}$. The 1969 Ozernoi earthquake was followed by a tsunami with local runup of 5-7 m from Karaginskii Bay south, with a local maximum of about $10 \mathrm{~m}$ on the Ozernoi Peninsula (Zayakin, 1981).

Around the Ozernoi and Kamchatskii Peninsulas, we have mapped the 1969 tsunami deposit (above the 1964 Shiveluch tephra or the 1956 Bezymianniy tephra) and expanded the runup catalogue for this tsunami to all our field sites in the southwestern Bering Sea. Moreover, we have found facies evidence of post-1956 subsidence (peat containing 1956 Bezymianniy tephra overlain by lagoonal mud) at the northern and southern extremes of the Ozernoi Peninsula, which we interpret to be coseismic with 1969. Using these data, a tide gauge record, and Daughton's fault-plane solution, Vasily Titov (Bourgeois et al., 2004) 
modeled this tsunami with $4 \mathrm{~m}$ of fault offset, corresponding to $3.5 \mathrm{~m}$ horizontal shortening.

Extrapolating this analysis to the paleoseismic record, we roughly estimate a rate of horizontal shortening for this region. Based on the record of prehistoric tsunami deposits, the average recurrence interval for Ozernoi-like events is 100-200 years (Bourgeois et al., 2006). Taking the maximum of 200 years, and using a $3 \mathrm{~m}$ shortening for 1969 , we calculate the long-term convergence of the Ozernoi Peninsula (Okhotsk block) with the Komandorskii Basin (Bering block) to be roughly 20 $\pm 10 \mathrm{~mm} / \mathrm{yr}$.

\section{DISCUSSION AND CONCLUSIONS}

Our findings throw light on local plate boundaries in this poorly studied region. Uplift rates of the Ozernoi Peninsula are comparable to rates on tectonically active margins (Lajoie, 1986; Ota and Yamaguchi, 2004), if less than rates on the Kamchatskii Peninsula, a small collisional orogen.

Whereas the source of shortening on the Kamchatskii Peninsula is well established, on Ozernoi it is not. The Ozernoi Peninsula exhibits uplift rates of $0.1-0.3 \mathrm{~mm} / \mathrm{yr}$ and evidence of compression and shortening via earthquakes such as that in 1969 and those inferred from prehistoric tsunamigenic earthquakes. Convergence rates on the order of 20 $\mathrm{mm} / \mathrm{yr}$ are consistent with these observations and analyses. Possible sources of this convergence include (1) shear distributed from the Pacific plate, north of the Komandorskii Island block (Fig. 1B), (2) existence of a clockwise-rotating Bering block (Mackey et al., 1997), and (3) existence and eastward extrusion of the Okhotsk block (Cook et al., 1986). In examining these possibilities, and using our new data, we reject shear distribution from the Pacific plate because of lack of seismicity in the Komandorskii Basin, distance $(150 \mathrm{~km})$ of the Ozernoi Peninsula from the active subduction zone, and the torn-slab model (Park et al., 2002) (no Pacific plate under this region).

Uplift and tilting of the Ozernoi Peninsula along with apparent reactivation of a thrust fault such as the boundary of the Olyutorskii terrane (Fig. 1B) shows that convergence is ongoing in this region. A slowly clockwiserotating Bering block (as in Mackey et al., 1997), in combination with eastward movement of an Okhotsk block, relative to the Komandorskii Basin (Fig. 1), may produce enough convergence to explain these observations. Moreover, the northern boundary of the Okhotsk block, which has been shown in different positions (e.g., McElfresh et al., 2002), must lie north of the Ozernoi Peninsula. In any case, neotectonic activity (Quaternary uplift, deformation, and seismicity) on the Ozernoi Peninsula is not consistent with an unbroken North American plate model, be- cause in this model, the source of deformation north of the northwestern corner of the Pacific plate is not explained.

\section{ACKNOWLEDGMENTS}

We thank Brian Atwater and Breanyn MacInnes for critiques of earlier versions of this manuscript; Jeremy Hourigan, Elizabeth Miller, and Tom Gardner for their helpful reviews; and Victor Morozov for field assistance. This study pertains to activities of the International Geological Correlation Program's Project 495 Land-Ocean interaction. The research was supported by grant EAR0125787 from the U.S. National Science Foundation.

\section{REFERENCES CITED}

Bourgeois, J., Titov, V., and Pinegina, T., 2004, Subduction-zone behavior backed out of tsunami deposits, Kamchatka, Far Eastern Russia: JapanKuril-Aleutian Workshop on Subduction Processes (JKASP), p. 97-98.

Bourgeois, J., Pinegina, T., Ponomareva, V., and Zaretskaia, N., 2006, Holocene tsunamis in the Bering Sea, Russian Far East: Tectonic implications: Geological Society of America Bulletin (in press).

Braitseva, O.A., Ponomareva, V.V., Sulerzhitsky, L.D., Melekestsev, I.V., and Bailey, J., 1997, Holocene key-marker tephra layers in Kamchatka, Russia: Quaternary Research, v. 47 , p. 125-139, doi: 10.1006/qres.1996.1876.

Cook, D.B., Fujita, K., and McMullen, C.A., 1986, Presentday plate interactions in northeast Asia: North American, Eurasian and Okhotsk plates: Journal of Geodynamics, v. 6 , p. $33-51$, doi: $10.1016 /$ 0264-3707(86)90031-1.

Cormier, V.F., 1975, Tectonics near junction of Aleutian and Kuril-Kamchatka arcs and a mechanism for middle Tertiary magnetism in Kamchatka Basin: Geological Society of America Bulletin, v. 86, p. 443-453, doi: 10.1130/0016-7606(1975) 86<443:TNTJOT $>2.0 . \mathrm{CO} ; 2$

Daughton, T.M., 1990, Focal mechanism of the 22 November 1969 Kamchatka earthquake from teleseismic waveform analysis: Third Keck Symposium in Geology, April 1990, Smith College, Northampton, Massaschusetts, p.128-131.

DeMets, C., Gordon, R.G., Argus, D.F., and Stein, S., 1994, Effect of recent revisions to the geomagnetic reversal time scale on estimates of current plate motions: Geophysical Research Letters, v. 21, p. 2191-2194, doi: 10.1029/94GL02118.

Douglas, B.C., Kearney, M.S., and Leatherman, S.P., editors, 2001, Sea-level rise: History and consequences: San Diego, California, Academic Press, $232 \mathrm{p}$

Gaedicke, C., Baranov, B., Seliverstov, N., Alexeiev, D., Tsukanov, N., and Freitag, R., 2000, Structure of an active arc-continent collision area: The AleutianKamchatka junction: Tectonophysics, v. 325, p. 63-85, doi: 10.1016/S0040-1951(00)00131-1.

Garver, J.I., Soloviev, A.V., Bullen, M.E., and Brandon, M.T., 2000, Towards a more complete record of magmatism and exhumation in continental arcs using detrital fission track thermochronometry: Physics, Chemistry and Earth Sciences, Part A, v. 25, p. 565-570, doi: 10.1016/S1464-1895(00)00086-7.

Geist, E.L., and Scholl, D.W., 1994, Large-scale deformation related to the collision of the Aleutian Arc with Kamchatka: Tectonics, v. 13, p. 538-560, doi: 10.1029/94TC00428.

Gordeev, E.I., Gusev, A.A., Levin, V.E., Bakhtiarov, V.F., Pavlov, V.M., Chebrov, V.N., and Kasahara, M., 2001, Preliminary analysis of deformation at the Eurasia-Pacific-North America plate junction from GPS data: Geophysical Journal International, v. 147 , p. $189-198$, doi: $10.1046 /$ j.0956540x.2001.01515x.

Hearty, P.J., and Kindler, P., 1995, Sea-level highstand chronology from stable carbonate platforms (Bermuda and the Bahamas): Journal of Coastal Research, v. 11, p. 675-689.

Imbrie, J., Hays, J.D., Martinson, D.G., McIntyre, A., Mix, A.L., Morley, J.J., Pisias, N.G., Prell, W., and Shackleton, N.J., 1984, The orbital theory of Pleistocene climate: Support from revised chronology of the marine ${ }^{18} \mathrm{O}$ record, in Berger, A., et al., eds.,
Milankovitch and climate: Dordrecht, Netherlands, Reidel, p. 269-305.

Johnson, M.E., and Libbey, L., 1997, Global review of upper Pleistocene (substage 5e) rocky shores: Tectonic segregation, substrate variation, and biological diversity: Journal of Coastal Research, v. 13, p. 297-307.

Kukla, G.J., and 21 others, 2002, Last interglacial climates: Quaternary Research, v. 58, p. 2-13.

Lajoie, K.R., 1986, Coastal tectonics, in Active tectonics: Impact on society: National Academy Press, Studies in Geophysics, p. 95-124.

Mackey, K.G., Fujita, K., Gunbina, L.V., Kovalev, V.N., Imaev, V.S., Kozmin, B.M., and Imaseva, L.P. 1997, Seismicity of the Bering Strait region: Evidence for a Bering block: Geology, v. 25 p. 979-982, doi: 10.1130/0091-7613(1997)025 $<0979$ :SOTBSR $>2.3 . \mathrm{CO} ; 2$.

Mackey, K.G., Nichols, M.L., Fujita, K., Gounbina, L.V., and Koz'min, B.M., 2004, The seismicity and crustal structure of continental eastern Russia: Eos (Transactions, American Geophysical Union), v. 85, Abstract GP43C-03.

McElfresh, S.B.Z., Harbert, W., Ku, C.-Y., and Lin, J.-S., 2002, Stress modeling of tectonic blocks at Cape Kamchatka, Russia using principal stress proxies from high-resolution SAR: New evidence for the Komandorskiy block: Tectonophysics, v. 354 p. 239-256, doi: 10.1016/S0040-1951(02)00341-4.

Muhs, D.R., 2002, Evidence for the timing and duration of the Last Interglacial period from high-precision uranium-series ages of corals on tectonically stable coastlines: Quaternary Research, v. 58 , p. $36-40$, doi: 10.1006/qres.2002.2339.

Muhs, D.R., Simmons, K.R., and Steinke, B., 2002, Timing and warmth of the Last Interglacial period: New U-series evidences from Hawaii and Bermuda and a new fossil compilation for North America: Quaternary Science Reviews, v. 21, p. 1355-1383, doi: 10.1016/S0277-3791(01)00114-7.

Ota, Y., and Yamaguchi, M., 2004, Holocene coastal uplift in the western Pacific Rim in the context of late Quaternary uplift: Quaternary International, v. 120, p. 105-117, doi: 10.1016/j.quaint.2004.01.010.

Park, J., Levin, V., Brandon, M., Lees, J., Peyton, V., Gordeev, E., and Ozerov, A., 2002, A dangling slab, amplified arc volcanism, mantle flow and seismic anisotropy in the Kamchatka plate corner, in Stein S., and Freymueller, J.T., eds., Plate boundary zones: American Geophysical Union Geodynamics Series, v. 30, p. 295-324.

Portnyagin, M., Hoernle, K., Avdeiko, G., Hauff, R., Bindeman, I., Uspensky, V., and Garbe-Schoenberg, D. 2005, Transition from arc to oceanic magmatism at the Kamchatka-Aleutian junction: Geology, v. 33, p. 25-28, doi: 10.1130/G20853.1.

Seliverstov, N.I., 1998, Structure of the floor of Kamchatka-related waters and geodynamics of the articulation zone of the Kuril-Kamchatka and Aleutian island arcs: Moscow, Scientific World, 164 p. (in Russian).

Steblov, G.M., Kogan, M.G., King, R.W., Scholz, C.H., Bürgmann, R., and Frolov, D.I., 2003, Imprint of the North American plate in Siberia revealed by GPS: Geophysical Research Letters, v. 30, doi: 10.1029/2003GL017805, $4 \mathrm{p}$

Takahashi, H., Kasahara, M., Kimata, F., Miura, S., Heki, K., Seno, T., Kato, T., Vasilenko, N., Ivashchenko, A., Bakhtiarov, V., Levin, V., Gordeev, E., Korchagin, F., and Gerasimenko, M., 1999, Velocity field of around the Sea of Okhotsk and Sea of Japan regions determined from a new continuous GPS network data: Geophysical Research Letters, v. 26, p. 2533-2536, doi: 10.1029/1999GL900565.

Zayakin, Y.A., 1981, The tsunami of 23 November 1969 at Kamchatka Peninsula and features of its origin Meteorologiya i Gidrologiya, v. 12, p. 77-83 (in Russian, English abstract).

Zazo, C., 1999, Interglacial sea levels: Quaternary International, v. 55, p. 101-113, doi: $10.1016 / \mathrm{S} 1040$ 6182(98)00031-7. 